JOPPAS: Journal of Public Policy and Administration Silampari

Volume 1, Nomor 2, Juni 2020

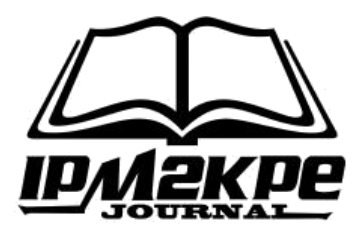

\title{
KOMUNIKASI DAN MOTIF PENGGUNAAN TOAH MASJID KECAMATAN DEPOK YOGYAKARTA
}

\author{
Alen Manggola \\ Universitas Islam Negeri Sunan Kalijaga Yogyakarta \\ manggolaa@gmail.com
}

\begin{abstract}
ABSTRAK
Tujuan penelitian ini adalah untuk mengetahui komunikasi dan motif penggunaan Toah Masjid Kecamatan Depok Yogyakarta. Penelitian ini menggunakan penelitian kualitatif dengan menggunakan metode analisis deskripsi. Teori yang digunakan adalah model komunikasi dua tahap dan teori fenomenologi yang dikemukakan oleh Alfred Schutz. Hasil penelitian ini menunjukkan bahwa penerapan kebijakan tuntunan penggunaan pengeras suara di masjid dapat diidentifikasi melalui komunikasi dua tahap yang dijalin antara Kanwil dengan penyuluh dan dari penyuluh kepada Takmir masjid. Komunikasi dua tahap dengan menggunakan Komunikasi Interpersonal dan Komunikasi Sosial. Peran penting penyuluh kebijakan sebagai gatekeeper dan opinion leader pada sosialisasi kebijakan publik. Simpulan, motif menggunakan pengeras suara masjid kearah luar selain daripada adzan di beberapa masjid Kecamatan Depok, seperti bacaan sholat, dzikir, do'a, sholawat dan pengumuman karena belum mendapat sosialisasi kebijakan, tidak ada yang mempermasalahkan penggunaannya, untuk menarik perhatian orang lain.
\end{abstract}

Kata Kunci: Komunikasi, Motif, Toah Masjid

\begin{abstract}
The purpose of this study was to determine the communication and motives for the use of Toah Masjid, Depok Yogyakarta District. This study uses qualitative research using description analysis methods. The theory used is a two-stage communication model and a phenomenological theory put forward by Alfred Schutz. The results of this study indicate that the application of guidelines for the use of loudspeakers in the mosque can be identified through two-stage communication that is established between the Regional Office with the instructor and from the instructor to the mosque Takmir. Two-stage communication using Interpersonal Communication and Social Communication. The important role of policy counselors as gatekeepers and opinion leaders in public policy socialization. Conclusion, the motive of using mosque loudspeakers to the outside other than the call to prayer in several mosques in the Sub-district of Depok, such as reading prayers, dhikr, prayers, prayers and announcements because they have not received policy socialization, no one has questioned their use, to attract the attention of others.
\end{abstract}

Keywords: Communication, Motives, Mosque Toah 


\section{PENDAHULUAN}

Kata atau istilah komunikasi pada dasarnya terjemahan dari bahasa Inggris yaitu Communication yang berkembang di Amerika Serikat yang menurut sejarahnya berawal dari unsur persurat kabaran, yaitu journalism. Komunikasi secara definisnya dapat dilihat dari dua sudut pandang, yakni; secara bahasa (etimologi) dan dari secara istilah (terminologi) Roudhonah (2007). Menurut bahasa (etimologi) dalam "Ensiklopedi Umum" diartikan dengan "perhubungan", sedangkan yang terdapat dalam buku komunikasi berasal dari perkataan latin, yaitu: Communicare, yang memiliki arti berpartisipasi ataupun memberitahukan. Selain itu Deddy Mulyana juga memberikan beberapa definisi komunikasi secara istilah yang dikemukakan beberapa pendapat para ahli antara lain: Gerald R.Miller, "Komunikasi terjadi ketika suatu sumber menyampaikan suatu pesan suatu penerima dengan niat yang disadari untuk mempengaruhi perilaku penerima." Menurut Effendy (2001) komunikasi merupakan suatu aktivitas yang sudah melekat pada setiap diri manusia, terlebih manusia sebagai makhluk sosial, maka dari itu komunikasi bersifat omnipresent (hadir dimana-mana).

Dapat disimpulkan bahwa secara umum komunikasi diprioritaskan untuk mencapai fungsinya sebagai upaya untuk mempersuasi hingga menimbulkan respon atau effect. Orang yang tidak pernah berkomunikasi dengan manusia, bisa dipastikan akan tersesat, karena ia tidak berkesempatan menata dirinya dalam suatu lingkungan sosial. Komunikasilah yang memungkinkan individu membangun suatu kerangka rujukan dan menggunakannya sebagai panduan untuk menafsirkan situasi apapun yang ia hadapi. Komunikasi pula yang memungkinkannya mempelajari dan menerapkan strategi-strategi adaptif untuk mengatasi situasi-situasi problematik yang ia masuki Mulyana (2005). Oleh sebab itu, komunikasi akan menentukan bagaimana seseorang dipandang, hingga akan dihargai sebagai teman dalam interaksi komunikasi yang telah berlangsung atau akan berlangsung. Karena komunikasi tidak hanya sebatas menyampaikan pesan namun juga bertujuan untuk mempengaruhi. Seseorang akan dapat mengubah sikap, pendapat, atau perilaku orang lain.

Menurut Thadi (2017) komunikasi sebagai ilmu yang multidisipliner dikembangkan melalui dukungan dari ilmu yang lainnya, demikian dalam mengungkap realitas sebagai objek telaah. Banyak realitas-realitas komunikasi yang harus dipotret dengan cara kerjasama antara ilmu komunikasi dengan ilmu-ilmu lainnya, seperti ilmu sosiologi, antropologi, psikologi, biologi, dan ilmu agama. Realitas tentang hubungan antara manusia dengan Allah SWT (ibadah) misalnya, dapat dianggap sebagai fenomena komunikasi.

Instruksi bimas islam tentang aturan penggunaan pengeras suara di masjid, langgar dan mushola telah ada sejak tahun 1978, kemudian dihadirkan kembali pada tahun 2018, yang dihimbau oleh menteri agama Republik Indonesia dengan kembali menginstruksi kepada Dirjen Bimas Islam melalui surat edaran. Terbitnya surat edaran tersebut mendapat 
tanggapan tak sedap di kalangan masyarakat. Pemerintah dianggap mengatur azan dengan meminta volume dikecilkan. Protes juga banyak disampaikan publik ke akun twitter Lukman sebagai Menteri Agama RI tersebut. Hadirnya sikap pemerintah mengeluarkan surat edaran tentang aturan penggunaan pengeras suara di masjid, langgar dan mushola bukan tanpa alasan. Pemerintah membuat aturan tersebut karena banyak pertanyaan dan permintaan masyarakat agar pemerintah membuat aturan tentang pengeras suara. Kemenag juga mengungkapkan kebijakan tersebut dilakukan dengan menilai banyaknya permintaan masuk terutama dari kota-kota besar dengan masyarakatnya yang heterogen.

Kemenag DIY mengungkapkan bahwa di yogyakarta masih ada masjid yang menggunakan pengeras suara tidak sesuai aturan kebijakan. Tentu hal ini didasari berbagai motif. Motif sangat cocok untuk menjadiakan sebuah sudut pandang evaluasi perencanaan kebijakan, sehingga memunginkan perlunya alternatif kebijakan untuk mengatasinya. Keadaan sosial masyarakat D.I Yogyakarta terkenal dengan kerukunan dan toleransinya yang memiliki keistimewaan tersendiri. Salah satu keistimewahannya adalah bahwa Yogyakarta pernah mendapat penghargaan kota dengan kehidupan beragama paling rukun di Indonesia versi Kemenag. Bukan hanya itu, Yogyakarta juga menjadi model percontohan keberagamaan untuk dunia dan asia. Oleh sebab itu keadaan sosial yang sangat istimewa tersebut harus tetap dalam keadaan yang stabil walaupun kondisi sosial yang dipengaruhi oleh berbagai isu, termasuk isu tentang kebijakan pemerintah pusat yang mengatur tentang penggunaan pengeras suara di masjid, langgar dan mushola.

\section{METODE PENELITIAN}

Metode penelitian digunakan supaya penelitian dapat lebih tersusun, terarah serta rasional dengan menggunakan jenis dan teknik tertentu. Maka, jenis dan teknik yang digunakan dalam penelitian ini adalah metode studi deskriptif kualitatif. Sejalan dengan pendapat Arikunto (2006) bahwa penelitian kualitatif merupakan suatu jenis metode penelitian yang mempunyai karakteristik dan lebih tertarik menelaah fenomena-fenomena sosial serta budaya pada suasana yang berlangsung secara alamiah. Penelitian deskriptif memaparkan situasi atau peristiwa. Peneliti tidak mencari atau menjelaskan hubungan serta tidak menguji hipotesis Rakhmat (2008). Penelitian kualitatif adalah penelitian yang bermaksud untuk memahami fenomena tentang apa yang dialami oleh subjek penelitian secara holistik, dan dengan cara mendeskripsikan dalam bentuk kata-kata dan bahasa, pada suatu konteks khusus yang alamiah dan dengan memanfaatkan berbagai metode alamiah Moleong (2010).

\section{HASIL PENELITIAN}

Sosialisasi kebijakan tentang tuntunan penggunaan pengeras suara masjid telah dilaksanakan oleh Kanwil Kemenag Provinsi D.I Yogykarta. Dalam hal ini, Kanwil meminta bantuan penyuluh untuk mensosialisasikan kebijakan tersebut ke setiap 
kabupaten di provinsi D.I Yogyakarta, termasuk Kabupaten Sleman sampai pada Kecamatan Depok. Pesan kebijakan telah dikomunikasikan oleh penyuluh kepada sasaran sosialisasi yaitu para takmir di forum pertemuan, serta melalui media sosial sebagai sarana komunikasi antara penyuluh dengan para takmir masjid se-D.I Yogyakarta.

Penyuluh merupakan sosok yang berpengaruh dalam sosialisasi kebijakan publik. Penyuluh dipandang memiliki wawasan dan relasi yang sangat luas, sehingga penyuluh memiliki peran yang sangat penting disetiap pelaksaanaan sosialisasi kebijakan. Sehubungan dengan hal tersebut, adanya pelaksanaan sosialisasi kebijakan tentang tuntunan pengeras suara di Provinsi D.I Yogyakarta tak lepas dari adanya peran penyuluh Kanwil Kemenag D.I Yogakarta. Peran penyuluh dalam penerapan kebijakan tuntunan penggunaan pengeras suara di masjid dapat diidentifikasi melalui komunikasi dua tahap yang dijalin antara Kanwil dengan penyuluh dan dari penyuluh kepada Takmir masjid.

Pada komunikasi tahap pertama, pesan berupa kebijakan tentang penggunan pengeras suara masjid dari Kanwil tersebut diterima oleh penyuluh yang berperan sebagai gatekeeper. Pada tahap ini, telah terjadi komunikasi interpersonal antara Kanwil dengan penyuluh, selanjutnya penyuluh mengkaji kebijakan tersebut terlebih dahulu sesuai dengan strategi yang akan digunakan penyuluh. Kemudian pada tahap kedua, penyuluh sebagai opinion leader menyampaikan kebijakan tersebut kepada para takmir. Pada tahap ini, sosialisasi kebijakan penggunaan pengeras suara oleh penyuluh memberi pengaruh yang kuat terhadap pembentukan konsep diri para takmir. Dalam hal ini, para takmir menjadi paham bagaimana kebijakan tersebut dipandang dari sisi kebermanfaatannya untuk keberlangsungan sebuah masjid. Komunikasi terjalin melalui komunikasi sosial antara penyuluh dengan para takmir. Berdasarkan hasil penelitian dan pembahasan terkait motif penggunaan pengeras suara bagian luar masjid di Kecamatan Depok, maka dapat disimpulkan bahwa dibalik bacaan sholat, dzikir, do'a, sholawat dan pengumuman dengan menggunakan pengeras suara masjid ke arah luar tersebut tidak hanya sekedar menggunakan. Penggunaan tersebut sesungguhnya memiliki motif, adapun motif menggunakan pengeras suara masjid kearah luar selain daripada adzan adalah karena belum mendapat sosialisasi kebijakan, karena tidak ada yang mempermasalahkan penggunaannya, dan untuk menarik perhatian orang lain. Motif tersebut tidak serta merta dilakukan untuk kepentingan takmir akan tetapi ditujukan kepada khalayak di Kecamatan Depok. Dimana motif tersebut tersalurkan melalui pengeras suara masjid sejalan dengan fungsi pengeras suara sebagai media komunikasi.

\section{PEMBAHASAN}

\section{Komunikasi Dua Tahap}

Interaksi maupun hubungan antar manusia terbentuk dari adanya proses komunikasi. Proses komunikasi dalam hal ini terjalin melalui tahapan- tahapan komunikasi. Tahapan-tahapan komunikasi itu tersusun dari adanya beberapa macam bentuk komunikasi. 
Tahapan-tahapan komunikasi juga tidak hanya melibatkan satu macam proses dan bentuk komunikasi saja, namun terbentuk dari beragam bentuk dan proses yang saling berhubungan. Dalam kajian ilmu komunikasi, ada banyak ragam jenis dari tahapan-tahapan komunikasi dalam hubungannya dalam membangun hubungan yang efektif dan terus terjalin secara berkesinambungan. Salah satu jenis tahapan komunikasi yang dimaksud ialah Komunikasi Dua Tahap. Terkait hal tersebut, tahapan komunikasi dimulai dari Komunikasi Tahap Pertama yaitu antara Kanwil dengan penyuluh. Komunikasi belum tentu akan efektif apabila Kanwil langsung menyampaikan pesan kepada masyarakat dalam hal ini adalah Takmir masjid. Sebab dalam kontek ini, kebijakan dari instruksi direspon pro dan kontra, menyakut emosi religius masih menyala-nyala selepas peristiwa seorang warga non-muslim yang memprotes salah satu pengeras suara di masjid dilingkungannya yang berujung kasus penodaan agama. Berdasarkan hal tersebut maka Kanwil membutuhkan penyuluh yang dianggap mampu mensosialisasikan dengan tidak mengusik kestabilan sosial yang telah lama terjalin harmonis.

1. Tahap Pertama

Terkait dengan komunikasi dua tahap tersebut, dalam komunikasi tahap pertama pesan dikirimkan oleh komunikator kepada penyuluh yang berperan sebagai gatekeeper. Dalam hal ini, komunikasi tahap pertama diawali dengan menganalisis bagaimana awal mula komunikator berinteraksi dan berhubungan dengan penyuluh hingga pada hubungan kerjasama yang baik. Maka untuk mengkaji hal demikian, peneliti menggunakan Komunikasi Interpersonal sebagai landasan teori yang digunakan. Sehingga hal yang perlu dianalisis adalah bagaimana proses awal Kanwil menjalin hubungan dengan Jafar Arifin dalam pelaksanaan sosialisasi kebijakan tentang tuntunan penggunaan pengeras suara masjid di Kecamatan Depok hingga hubungan Kanwil dengan penyuluh tersebut sampai saat ini. Terjadinya komunikasi interpersoanal anatara Kanwil dengan penyuluh sudah dimulai sejak lama, tentunya semenjak aturan ada dan memberi hak Kanwil untuk mengurusi semua permasalahan masyarakat terkait dengan kebijakan yang perlunya campur tangan Kanwil, dan tidak hanya kebijakan tentang aturan penggunaan pengeras suara saja yang disampaikan.

2. Tahap Kedua

Komunikasi tahap kedua merupakan proses tahapan selanjutnya daripada komunikasi tahap pertama. Komunikasi tahap kedua membahas tentang proses komunikasi yang dijalin antara penyuluh dan Takmir. Dalam hal ini, komunikasi tahap kedua mengkaji bagaimana penyuluh membentuk pemahaman dan pandangan takmir terhadap kebijakan. Sebagaimana yang diungkapkan oleh Wiryanto (2006) bahwa komunikasi tahap kedua adalah membahas tentang bagaimana pesan kebijakan tersebut oleh penyuluh disampaikan kepada khalayaknya dalam hal ini adalah takmir. Hubungan antara Takmir dengan penyuluh tersebut membentuk interaksi melalui Komunikasi Sosial. Dari adanya proses Komunikasi Sosial sebagai pandangan penyuluh terhadap sesuatu hal yang 
berkaitan dengan agama yang sangat di percayakan oleh masyarakat akan pengetahuannya pada suatu hal berkaitan dengan apa yang disampaikannya. Peran penyuluh dalam komunikasi sosial tersebut sangat berpengaruh terhadap sosialisasi kebijakan pengeras suara di setiap Kabupaten Sleman khususnya Kecamatan Depok.

\section{Motif Penggunaan Pengeras Suara Masjid}

Penggunaan pengeras suara merupakan fenomena yang telah menyebar ke setiap lapisan masyarakat muslim baik pada mushola, langgar dan tidak terkecuali masjid yang mayoritas. Berdasarkan pengamatan, peneliti menemukan bahwa penggunaan pengeras suara kearah luar selain merupakan untuk adzan di Kecamatan Depok masih ada beberapa masjid melakukannya, seperti pengeras suara juga digunakan untuk sholawatan dan pengumuman informasi warga. Bahasan dalam hal ini, yang terpenting bagi peneliti tidak hanya sekedar adzan yang menggunakan pengeras suara ke arah luar, melainkan motif menggunakan pengeras suara luar selain daripada adzan. Sebab, pada dasarnya motif tersebutlah yang akan mempengaruhi dan mendorong tindakan seseorang seperti yang telah dijelaskan sebelumnya. Berdasarkan fenomena yang ada, pada sub bab ini peneliti tertarik untuk menulis tentang motif menggunakan pengeras suara masjid ke arah luar selain daripada adzan. Masalah yang akan dibahas pada sub bab ini adalah apakah yang menjadi motif menggunakan pengeras suara masjid kearah luar selain daripada adzan. Teori yang digunakan adalah teori fenomenologi yang dikemukakan oleh Alfred Schutz. Inti pemikirannya adalah bagaimana memahami tindakan sosial (yang berorientasi pada perilaku orang atau orang lain pada masa lalu, sekarang dan akan datang) mealui penafsiran.

Untuk menggambarkan seluruh tindakan seseorang, maka Schutz mengelompokan dalam dua tipe motif, yaitu: (a) Motif Tujuan (In-order-to-motive), (b) Motif Karena (Because motive). Berdasarkan data penelitian yang telah peneliti lakukan mengenai motif penggunaan pengeras suara luar selain adzan di beberapa masjid pada Kecamatan Depok. Peneliti menemukan tiga hal yang menjadi motif di beberapa masjid Kecamatan Depok dalam menggunakan pengeras suara luar dengan menggunakan beragam aktivitas ibadah yang dilakukan seperti: sholawatan, bacaan sholat, dzikir, do'a, penyetelan kaset morotal mengaji, dan juga pengumuman warga, seharusnya berdasarkan kebijakan penggunaan pengeras suara bahwa semua itu seharusnya menggunakan pengeras suara dalam (Mulyana, 2010). Adapun motif tersebut sebagai berikut:

1. Belum Mendapat Sosialisasi

Ketidakpatuhan salah satu penyebab utamanya adalah karena tidak tahu akan informasi. Penggunaan pengeras suara telah menjadi bagian penting dari kehidupan umat muslim sebagai media yang membantu berjalannya aktivitas ibadah. Berdasarkan keeksisannya tersebut maka ada yang mengaturnya, termasuk penggunaan suara bagian luar masjid. Namun, berdasarkan keterangan beberapa takmir yang mengungkapkan bahwa belum 
pernah mendapatkan sosialisasi tentang aturan tersebut. Tentu dengan sebab belum pernah mendapatkan sosialisasi akan menjadi motif sehingga bisa menjadi dalih terampuh kenapa melakukan demikian yang tidak sejalan dengan aturan yang berlaku.

2. Tidak Ada Yang Mempermasalahkan

Menjalin kerjasama antar individu masyarakat untuk sebuah keharmonisan adalah membuat toleransi semakin dalam. Demikian juga dengan penggunaan pengeras suara masjid bagian luar tidak dipermasalahkan oleh masyarakat. Sebab, pemahaman menganggap hal tersebut sudah semestinya menjadi sebuah kebudayaan dalam peribadahan suatu umat. Kemudian, saling membantu membuat kesensitifan terhadap suatu agama akan hilang dengan semakin dalam hubungan yang dijalin. Sebagaimana motif penggunaan pengeras suara yang menggambarkan bahwa tidak ada masalah menggunakan selama memahami bahwa tidak untuk terlalu berlebihan. Kerjasama antar umat beragama membuat kehidupan beragama menjadi lebih harmonis. Berdasarkan ungkapan beberapa takmir bahwa bentuk penguatan toleransi ialah penggunaan pengeras suara masjid bagian luar digunaan untuk menyampaikan berita lelayu baik warga muslim ataupun non-muslim. Kemudian masjid digunakan sebagai sarana berkumpulnya masyarakat tanpa terkecuali seperti rapat RT, arisan RT dan lain sebagainya yang tentunya berkaitan dengan kepentingan umum namun dibantu oleh sarana umat muslim yaitu pengeras suara masjid.

3. Untuk Mendapatkan Perhatian Masyarakat

Kehadiran pengeras suara masjid sebagai media komunikasi dalam penyampaian informasi terkait kegiatan masjid. Adapun komunikasi yang efektif apabila jelas tersampaikan, termasuk terdengarnya informasi melalui suara yang dihasilkan pengeras suara, terkhusus pengeras suara bagian luar masjid. Sejalan dengan keefektifannya memungkinkan takmir masjid menggunakan pengeras suara bagian luar agar terdengar oleh masyarakat, seperti sholawatan, pengumuman dan lain sebagainya. Berdasarkan banyaknya keterangan terkait penggunaan pengeras suara masjid bagian luar, ternyata motif yang mendasarinya adalah untuk menarik perhatian masyarakat. Motif dilakukan dengan tujuan yang tentu penting menurut sebagian pihak masjid, adapun tujuan kenapa perlunya menarik perhatian orang lain adalah untuk membangunkan masyarakat muslim supaya lebih siap untuk melaksanakan ibadah. Dianggap bisa menghidupkan suasana masjid. Kemudian, penggunaan pengeras suara dianggap lebih efektif menjangkau pendengaran masyarakat selain pesan ditulis dalam lembaran kertas sebagai media yang juga dilakukan untuk memberi informasi terkait kepentingan warga.

\section{SIMPULAN}

Kanwil Kemenag DIY dalam hal ini, selalu menjalin relasi terhadap penyuluh melalui komunikasi interpersonal, sebab menggunakan mereka sebagai sosok sentral yang berpengaruh dalam pelaksanaan sosialisasi kebijakan masih efektif. Perannya dalam 
merangkul atau mengajak masyarakat agar terus meningkatkan kesadaran dalam menerapkan suatu kebijakan.

Terkhusus para takmir, sebab mereka lebih mudah mempercayai para penyuluh sebagai opinion leader dibandingkan pemerintah sendiri. Ini diakibatkan dari kedekatan penyuluh dengan masyarakat atau takmir melalui forum pertemuan sebagai sarana komunikasi. Komunikasi dua tahap merupakan metode komunikasi yang dianggap cukup efektif dalam pelaksanaan sosialisasi kebijakan. Seperti komunikasi antara Kanwil dengan penyuluh lalu kemudian kepada masyarakat.

Diharapkan dapat menjadi alternatif kebijakan ketika kebijakan tidak memungkinkan untuk disosialisasikan secara langsung dari pemerintah kepada masyarakat. Sebab tidak semua kebijakan akan direspon baik oleh masyarakat. Aneka ragam motif penggunaan pengeras suara masjid menjadi hal krusial dalam kehidupan masyarakat. Jadi, penelitian diharapkan memberikan referensi yang cukup baik untuk bebagai daerah di tanah air ini.

\section{DAFTAR PUSTAKA}

Arikunto, S. (2006). Prosedur Penelitian Suatu Pendekatan Praktek. Jakarta: Rineka Cipta Effendy, O. U. (2001). Ilmu Komunikasi Teori dan Praktek. Bandung: PT. Remaja Rosdakarya

Effendy, O.U. (2008). Ilmu, Teori dan Filsafat Komunikasi. Bandung: PT Citra Aditya Bakti

Moleong, L., J. (2010). Metode Penelitian Kualitatif. Bandung: PT. Remaja Rosdakarya

Mulyana, D. (2005). Ilmu Komunikasi; Suatu Pengantar. Bandung: PT Remaja Rosdakarya

Mulyana, D. (2010). Ilmu Komunikasi Suatu Pengantar. Bandung: PT. Remaja Rosdakarya Rakhmat, J. (2008). Riset Komunikasi. Bandung: PT Remaja Rosdakarya

Roudhonah, R. (2007). Ilmu Komunikasi. Jakarta: Jakarta Pers

Thadi, R. (2017). Komunikasi Transendental: Shalat sebagai Bentuk Komunikasi Transendent. Jurnal Ilmiah Syi'ar, 17(2), 43-52

Wiryanto, W. (2006). Pengantar Ilmu Komunikasi. Jakarta: Grasindo 